\title{
Коммодификация природы: национальный парк «Ладожские шхеры»'
}

\author{
А.Ю. ОСИПОВ*, М. ЛЯХТЭЭНМЯКИ**, О. ИЛМОЛАХТИ***, Я. КАРХУ****
}

\begin{abstract}
*Александр Юрьевич Осипов - кандидат исторических наук, научный сотрудник, Департамент истории и географии, Университет Восточной Финляндии (Йоэнсуу, Финляндия). Адрес: Box 111, 80100 Joensuu, Finland. E-mail: alexander.osipov@uef.fi **Мария Ляхтээнмяки - доктор философии, профессор истории, Департамент истории и географии, Университет Восточной Финляндии (Йоэнсуу, Финляндия). Адрес: Bох 111, 80100 Joensuu, Finland. E-mail: maria.lahteenmaki@uef.fi

***Оона Илмолахти - доктор философии, научный сотрудник, Департамент истории и географии, Университет Восточной Финляндии (Йоэнсуу, Финляндия). Адрес: Box 111,80100 Joensuu, Finland. E-mail: oona.ilmolahti@uef.fi

****Яни Карху - магистр истории, научный сотрудник, Департамент истории и географии, Университет Восточной Финляндии (Йоэнсуу, Финляндия). Адрес: Вох 111, 80100 Joensuu, Finland. E-mail: jani.karhu@uef.fi

Цитирование: Осипов А.Ю., Ляхтээнмяки М., Илмолахти О., Карху Я. (2019) Коммодификация природы: национальный парк «Ладожские шхеры» // Мир России. Т. 28. № 3. C. 113-131. DOI: 10.17323/1811-038X-2019-28-3-113-131
\end{abstract}

В статье исследуются проблемь коммодификации природы Северного Приладожья и мнения участников событий относительно использования природных ресурсов. Судьба уникальных природных ландшафтов, подвергшихся серьезному антропогенному воздействию, стала предметом длительной дискуссии между властями разных уровней, ученьми и местными жителями. Создание национального парка «Ладожские шхеры» явилось не только гарантом сохранения природного комплекса, но и затронуло права местных жителей, объединившихся против этой идеи. На основании широкого круга неопубликованных документов, интервью и данных интернет-форумов авторы демонстрируют, как природные ландшафты Северного Приладожья выступают в качестве визуальньх объектов, при этом экотуризм принимает на себя роль инструмента коммодификации. Наряду с этим, местные жители рассматривают эту территорию как жизненное пространство и объект материального потребления. Таким образом, ситуация вокруг национального парка представляется классическим примером противоречия между коллективным и индивидуальным. Анализ ответов респондентов приводит авторов к выводу, что суть

1 Исследование выполнено в рамках проекта Green Zone Project при поддержке фонда Коне (Kone Foundation). 
конфликта заключается не только в разных способах коммодификации природы. Национальный парк нарушает невидимые границы жизненного пространства, выстроенные местными жителями, и является инородной структурой. Авторы показывают, как данная проблема выходит на политический уровень, где противники парка терпят поражение, при этом сам конфликт остается неурегулированным.

Ключевые слова: коммодификация, жизненное пространство, национальный парк, природный ландшафт, туризм, социально-экологический конфликт

В конце 2017 г. в Республике Карелия был создан четвертый национальный парк «Ладожские шхеры». Ни одна из образованных ранее в регионе охраняемых природных территорий не вызывала столько споров, которые велись на протяжении последних тридцати лет. В этой статье речь пойдет не только об истории национального парка, поскольку нарратив является скорее фоном. Основное внимание в статье будет уделено позиции местных жителей (преимущественно из города Сортавала) в отношении образования парка «Ладожские шхеры», тому, как город, встроенный в природу Северного Приладожья, воспринимает национальный парк. Эта проблема укладывается в рамки энвайронментологии (истории охраны окружающей среды), которая до настоящего времени не получила широкого распространения в России. Сужая фокус исследования до анализа социально-экологического конфликта, мы вынуждены констатировать, что историография этой проблематики довольно скудна. Безусловно, стоит упомянуть работы О.Н. Яницкого, О.В. Аксеновой, Д.В. Ефременко [Аксенова 2017; Яницкий 2016; Ефременко 2006; ], в которых дискурс направлен на методологию и теорию производства экосоциального знания, а также на изучение политического регулирования взаимодействия человека и природы.

Непосредственно социально-экологические конфликты чаще всего рассматриваются в русле строительства различных промышленных объектов и загрязнения природы. Подобные случаи привлекают внимание не только ученых, но и общественности: характерным примером можно назвать строительство трассы Москва-Санкт-Петербург и скандал вокруг вырубки Химкинского леса. Ситуация с национальным парком «Ладожские шхеры» оказывается противоположной: парк вторгается в пространство местных жителей и нарушает привычной образ жизни. Впрочем, этот пример не единичен: Алтайский биосферный заповедник, Шорский национальный парк, природный парк Уч-Энмек создавались так же, несмотря на противодействия со стороны местного населения [Садовой 2012].

История образования национального парка «Ладожские шхеры», к сожалению, никак не отражена в научной литературе, а существующие исследования посвящены преимущественно биологическим и экологическим аспектам. Основой для написания этой статьи стали неопубликованные документы из Национального архива Республики Карелия (НАРК) и архива Карельского научного центра Российской академии наук (КарНЦ РАН), материалы местной прессы и данные экологических организаций. Наиболее ценными источниками представляются сведения, опубликованные на интернет-форумах, где происходит обмен мнениями между сторонниками и противниками парка. Кроме того, в работе использованы интервью с представителями местной власти, собранные в 2013 г. после наиболее горячих дискуссий. 


\section{Возникновение ландшафта}

Территория Северного Приладожья знаменита своими уникальными природными ландшафтами: ладожские шхеры образуют сотни заливов, проливов и островов и не имеют аналогов на карте пресноводных водоемов Европы. Эта область также является местом обитания кольчатой нерпы и других редких видов животных, занесенных в различные Красные книги. Северное Приладожье, будучи приграничной территорией, неоднократно переходило под юрисдикцию соседних государств, испытав на себе русское, шведское и финское влияние и благодаря этому сохранив различные объекты культурного наследия. Не затрагивая глубоко историю региона, отметим, что с конца XIX в. Северное Приладожье, оставаясь еще частью Великого княжества Финляндского, превратилось в популярное туристское направление и активно рекламировалось в путеводителях того периода [Rajaseutujen matkailuopas 1927; Vartiainen 1932; Siiskonen 1994, pp. 123-124]. Туристов, преимущественно финнов, привлекали не только расположенный рядом остров Валаам и его монастырь, но и природа ладожских шхер. Финские справочники 20-30-х гг. XX в. красочно описывали местные достопримечательности и предлагали посетителям ландшафтный туризм - осмотр окрестностей со специально сооруженных смотровых башен [Laatokan pohjoisrannikon kulttuuriympäristö 1998, pp. 134-135]. О значимости этих мест свидетельствует и тот факт, что в 1877 г. вид на Ладогу с острова Риеккалансаари был помещен на финскую банкноту достоинством 500 марок [Vartiainen 1932, p. 7].

Впрочем, период конца XIX - начала XX вв. в истории Приладожья, называемый «золотым временем ландшафтного туризма» [Laatokan pohjoisrannikon kulttuuriympäristö 1998, p. 134], вряд ли стоит идеализировать, поскольку регион приобрел известность также благодаря активно применявшемуся подсечно-огневому земледелию2 ${ }^{2}$ лесозаготовкам и богатым пастбищам [Vartiainen 1932, p. 6], из чего можно заключить, что территория подверглась значительному антропогенному воздействию, к которому стоит добавить и строительство дач.

Вторая мировая война также оставила свой отпечаток на ландшафтной карте, превратив территорию Приладожья в места сражений. C ее завершением граница была сдвинута на запад, и Ладожское озеро целиком оказалось на территории СССР. Фактор границы и наличие пограничной зоны затруднили доступ туристов к ладожским шхерам и частично способствовали консервации природы. Ликвидация хуторского земледелия и неперспективных деревень, а также отток сельского населения в город привели к деградации личных хозяйств и выбыванию из оборота отдельных земельных участков [Кравченко 2001, с. 30-31].

Заменой активного землепользования и хуторского земледелия в 1970-1980-е гг. стала индивидуальная застройка территории Северного Приладожья. Дачное строительство было популярно и в финский период, однако вектор коммодификации сместился: сельское хозяйство уступало место отдыху. Эта тенденция получила новый импульс в 1990-е гг. в связи с бумом дачного строительства, когда целые острова Северного Приладожья превращались в дачные поселки. Естественно, это

2 Согласно одной из версий, название города Сортавала, крупнейшего в Северном Приладожье, происходит от финского sortaa (вырубать лес для подсеки). 
коснулось в большей степени островов, расположенных в непосредственной близости от Сортавалы (о. Хавус и о. Риеккалансаари). Помимо дачной застройки, население Сортавалы и ближайших поселков Импилахти, Ляскеля, Хийденсельга активно использовало территорию в качестве места пляжного отдыха и рыбалки, сбора грибов и ягод. Поэтому идея обустройства национального парка, отчуждение территории и превращение ее в объект визуального потребления вызвали неприятие местных жителей и стали причиной конфликта между сортавальцами и республиканскими властями.

История создания парка позволяет продемонстрировать одно из классических противоречий современного общества между государственным и частным, которое приводит в своей работе «Изобретение повседневности» Мишель де Серто. Речь идет о противоречии между коллективным способом управления и индивидуальным способом присвоения [Серто 2013, с. 192]. Мишель де Серто отмечает, что город производит свое пространство, а практикой его присвоения становится акт ходьбы отдельного пешехода. Пешеход присваивает топографическое пространство, обходя существующие запреты и формируя социальные модели, культурные обычаи и личные факторы [Серто 2013, с. 193, 198]. В нашем случае акт ходьбы продуцирует многочисленные маршруты между городом и дачами, местами сбора грибов и ягод, пляжами и местами рыбалки.

Территория национального парка, граничащая с городом и присваиваемая ежедневными или сезонными практиками, является для местных жителей (пешеходов) жизненным пространством. В то же время сторонний наблюдатель видит в ней культурный или природный ландшафт, привлекательное туристское направление. Взгляд на город сверху обозначает его как конкретное место, картину, панораму, где практики нераспознаваемы, но на уровне пешехода именно практики организуют пространство и присваивают его. Отсюда вытекает различие между местом (физическими границами города) и пространством (пригородной территорией, присвоенной жителями); отсюда же происходит конфликт между местными жителями и властями, с одной стороны, и федеральными властями, республиканским центром, экологами и учеными, с другой. Демонстрация этого конфликта через анализ повседневных практик жителей города представляется главной задачей настоящей статьи. В основе этого спора находятся различные способы потребления природы: индивидуальный для горожан и рекреационный для республиканских властей. Создание национального парка имеет своей целью не только сохранение природы, но и использование ее в качестве туристского направления, где основным способом потребления становится экотуризм. Кроме того, история национального парка включает в себя и иные способы потребления природы (например, лесозаготовки).

\section{Формы коммодификации}

Идея создания охраняемой природной зоны в районе Северного Приладожья впервые была озвучена учеными Карельского филиала Академии наук СССР в конце 1989 г. ${ }^{3}$. Уже в следующем году, 28 июня 1990 г., Сортавальский совет на-

3 НАРК. Ф. 3741. Оп. 1. Д. 5. Л. 38-39. Сообщение от завлаборатории охраны природы А.А. Кучко. 16.03.1989. 
родных депутатов принял Постановление «Об организации на островной и прибрежной части Ладожского озера природного парка “Ладожские шхеры”», которое поддержали депутаты Питкярантского и Лахденпохского горсоветов ${ }^{4}$. Согласно предварительному проекту, территория парка включала в себя земли трех административных районов и составляла 85 тыс. га. Нет ничего удивительного в том, с какой скоростью было принято решение об обустройстве парка, поскольку оно стало продолжением политического курса, проводимого центральными властями: 27 ноября 1989 г. вышло Постановление Верховного Совета РСФСР «О неотложных мерах экологического оздоровления страны», в котором ставилась задача увеличить площади заповедников и национальных парков до $2 \%$ от общей площади земель страны к 1995 г. и до 3\% к 2000 г. ${ }^{5}$. Республиканские власти, в свою очередь, взяли за основу предложение ученых Карельского филиала АН СССР о формировании сети особо охраняемых природных территорий (ООПТ), куда входил и будущий природный парк «Ладожские шхеры» ${ }^{6}$

Начиная с первой половины 1990-х гг. региональные руководители неоднократно подчеркивали, что «Ладожские шхеры» - это приоритетное направление в сфере охраны природы Карелии ${ }^{7}$. Однако по ряду причин реализация проекта забуксовала. Во-первых, сложность заключалась в особенности расположения будущего парка, так как территория Северного Приладожья к тому времени была хорошо освоена, и при планировании приходилось учитывать близость города Сортавала, наличие оживленных трасс, и, самое главное, массива дач, туристических баз и мест отдыха на природе, располагавшихся на территории будущего парка. Образованные ранее в республике национальные парки «Паанаярви» и «Водлозерский» не испытали подобных проблем, поскольку находились в безлюдной либо малонаселенной местности. Вторым серьезным препятствием стали интересы бизнесменов-лесозаготовителей, против которых выступали журналисты, лесничие, экологи и ученые, высказывавшиеся за ограничение бесконтрольной рубки леса в Северном Приладожья [Тимофеев (1) 1991; Тимофеев (2) 1991; Экологический митинг 1991; Назаров 1992].

Проблема коммодификации природы нашла свое отражение и в дискуссии о статусе парка. Примечательно, что изначально речь шла об обустройстве природного, а не национального парка. Принципиальное различие этих типов ООПТ заключалось в их функциях: обустройство национальных парков преследовало прежде всего природоохранные цели, и вопросы рекреационного использования играли в них второстепенную роль, а природные парки создавались для развития туризма и массового отдыха населения. Кроме того, национальные парки включали в себя уголки первозданной природы с уникальными экосистемами, в то вре-

\footnotetext{
4 НАРК. Ф. 3741. Оп. 1. Д. 174. Л. 39. Информационное письмо от Комиссии по вопросам охраны природы и развития туризма РК в Совмин РК. 26.05.1993.

5 НАРК. Ф. 3741. Оп. 1. Д. 59. Л. 2. Письмо Госкомприроды о разработке программы создания единой системы ООПТ в республиканские, краевые и областные комитеты. 08.02.1990.

6 НАРК. Ф. 3741. Оп. 1. Д. 59. Л. 15,16. Объяснительная записка к предложению по организации ООПТ на период до 1995 и до 2000 гг. 11.04.1990.

7 НАРК. Ф. 3741. Оп. 1. Д. 174. Л. 39. Информационное письмо от Комиссии по вопросам охраны природы и развития туризма РК в Совмин РК. 26.05.1993; НАРК. Ф. 3741. Оп. 1. Д. 362. Л. 126. Проект постановления Председателя Правительства РК о создании природного парка «Ладожские шхеры». 06.12.1997.
} 
мя как природные парки могли учреждаться в местах нарушенного ландшафта ${ }^{8}$. Наконец, еще одно ключевое отличие заключалось в финансировании: национальные парки относились к федеральной собственности и получали средства из федерального бюджета, в то время как природные парки состояли на балансе республиканских властей. Эти разграничения были официально закреплены в законодательстве лишь в 1995 г. с принятием Федерального закона «Об особо охраняемых природных территориях» [Федеральный закон 1995].

Страницы центральной республиканской газеты «Ленинская правда» (впоследствии «Северный курьер») стали основной площадкой для дискуссии о статусе «Ладожских шхер». По сути, эти публикации явились первым публичным противостоянием между республиканской и районной властями в вопросе о статусе территории. Главный аргумент сторонников создания природного парка заключался в более мягком режиме этого типа охраняемых природных объектов, который, по их мнению, был более подходящим для обжитой территории Северного Приладожья [Жуков 1995; Интервью с Ширлиным 1997; Сыстра 1997]. Ведущий научный сотрудник Института геологии КНЦ РАН Ю. Сыстра утверждал, что придание «Ладожским шхерам» статуса национального парка резко ограничит права десятков тысяч собственников, также он настаивал на нецелесообразности передачи наиболее ценных карельских земель в федеральную собственность [Cыстра 1997].

Сторонники национального парка ссылались на федеральный закон, гарантировавший вывод частной собственности из территории парка. Вторым весомым аргументом являлся источник финансирования - федеральный бюджет, поскольку республиканские власти с трудом находили средства на содержание уже существующих охраняемых территорий регионального значения [Сазонов, Кравченко, Кузнецов 1997]. К слову сказать, сторонники национального парка явно лукавили, апеллируя к федеральному финансированию: национальные парки «Паанаярви» и «Водлозерский» в середине 1990-х гг. испытывали серьезный дефицит бюджета, о чем в местной прессе писали сотрудники и администрация парков [Водлозерье не только парк 1995; Семенов 1994].

Нельзя сказать, что разработчики не учитывали интересы местных жителей при планировании охраняемой территории: в проекте парка были обозначены проблемы дачных кооперативов и земель сельскохозяйственного назначения, однако выводы авторов оказались двойственными. По утверждению разработчиков, «в регионе существует благоприятная среда для реализации предложенного проекта. Это подтверждают данные опроса населения, а также интервью с руководителями местных администраций». Однако уже на следующей странице проекта авторы отмечали обратное: «Отношение местного населения к идее создания национального парка “Ладожские шхеры” - один из острых вопросов» [Морозова, Гурова, Козырева, Кулакова, Хаапала 2001, с. 25, 26].

В действительности, материалы карельской прессы свидетельствуют о том, что жители Северного Приладожья выступали против парка в какой бы то ни было форме, формулируя свои претензии так: «местных жителей никто не спрашивал», «решения принимались закулисно», «земля практически становится товаром,

8 Архив КарНЦ РАН. Ф. 2. Оп. 2. Д. 462. Л. 2,3. Предложение КНЦ по формированию сети ООПТ Карелии в Президиум ВС КАССР. 10.01.1991. 
а администрации парков - единоличными хозяевами», «простым людям не будет доступа в лес и на водоемы» [Мальковский, Тимофеев 1998]. Таким образом, на страницах республиканской прессы были впервые сформулированы интересы местных жителей, а также идея коммерциализации земли, и эти пункты впоследствии станут ключевыми в вопросе о судьбе парка.

В 1998 г. на страницах карельских СМИ впервые появился термин «экотуризм», предполагающий альтернативное использование природных ресурсов [Тимофеев, 1998]. Идея быстро обрела популярность: чиновники, ученые и представители турфирм заговорили о сельском, аграрном и природном видах туризма как о новых отраслях экономики, способных потеснить лесозаготовителей [Некрасов 1999; Казберович 2000; Ведлозерская 2001; Громцев 2001; Кагhи, Osipov 2017]. Дискуссии об экологическом туризме, основой которого должны были стать национальные парки, органично вписывались в общую концепцию развития туристской отрасли. На рубеже 1990-2000-х гг. с учетом увеличения посещаемости островов Кижи и Валаам как главных достопримечательностей края, на туризм в целом возлагались большие надежды [Интервью с Шороховым 1998; Прокопенко 1999; Смирнова 2001].

Помимо отрицательной позиции районных властей, интересов лесозаготовителей и жителей Сортавальского, Лахденпохского и Питкярантского районов, еще одним препятствием для образования парка оказалась нехватка финансирования, дефицит которого уже успели ощутить другие охраняемые территории. Помощь в этом вопросе пришла со стороны правительства Финляндии и Европейского союза: в 1997 г. в Карелии стартовали первые проекты в рамках программы TACIS (Technical Assistance to the Commonwealth of Independent States), а в 1999 г. была запущена масштабная программа «Развитие парков Карелии» с внушительным бюджетом в 3,5 млн евро [Интервью с Й. Хогмандером 1999], которая предусматривала разработку обоснований обустройства новых национальных парков, а также помощь уже существующим. В частности, проект национального парка «Ладожские шхеры» предполагал формирование полной инфраструктуры: строительство информационного центра, оборудование туристических маршрутов и стоянок, закупку инвентаря на общую сумму 38,5 млн руб. (в ценах 2001 г.). Кроме этого, в учрежденное муниципальное унитарное предприятие «Парк Ладожские шхеры» были переданы автомобили, лодки, снегоходы, офисная техника и другое имущество на общую сумму 182 тыс. евро [Кравченко 2001, с. 81-90]. По замыслу руководителей проекта, МУП должно было поддерживать инфраструктуру парка, развивать туризм и обслуживать посетителей до момента официального открытия. Таким образом, благодаря финансированию Европейского союза была проведена вся подготовительная работа по организации национального парка. Однако возникла парадоксальная ситуация, когда объект существовал фактически и даже принимал посетителей, но не имел статуса охраняемой природной территории, и исключительно удачный момент с возможностью дальнейшего финансирования в рамках проектов TACIS был упущен. Причинами этого, вероятно, явились несогласованность действий местных и центральных властей и политика государства в области охраны природы.

Забегая вперед, отметим, что на рубеже 1990-2000-х гг. экотуризм как таковой рассматривался в качестве панацеи для местной экономики не только властями Республики Карелия. Австралийские и европейские исследователи 
отмечали ошибочность подобного восприятия, традиционно завышенные ожидания местных властей и, как правило, несбывшиеся надежды в вопросе выхода местной экономики из кризиса с помощью развития экологического туризма [Hall, Boyd 2005; Page, Dowling 2002; Fullagar, Markwell, Wilson 2012]. Данные за 2014 г. демонстрируют, что экотуризм составлял лишь 4\% от общего туристского потока в Карелию9.

Статистика создания охраняемых природных территорий во второй половине 1990-х гг. в России выглядит весьма удручающе. Согласно распоряжению Правительства РФ от 23 апреля 1994 г., был сформирован Перечень государственных природных заповедников и национальных парков, рекомендуемых для организации на территории РФ в период 1994-2005 гг. Этот Перечень предусматривал образование 114 новых объектов к 2005 г, из которых было реализовано лишь 23 [Степаницкий, Крейндлин 2004, с. 24-25]. В конечном итоге в 2001 г. распоряжение было отменено, а планы существенно сокращены. При этом ключевым для Республики Карелия оказался тот факт, что парк «Ладожские шхеры» не был включен в новый список, в отличие от Калевальского парка; кроме того, начиная с 1999 г. Министерство финансов России фактически объявило негласный мораторий на устройство новых заповедников и национальных парков [Степаницкий, Крейндлин 2004, с. 25]. Тем самым идея национального парка была отложена на неопределенный срок, а освоение территории Северного Приладожья продолжилось.

Снижение интереса к идее национальных парков четко прослеживается на примере районной и республиканской прессы, которая является своеобразным индикатором актуальности проблемы: в 2001-2007 гг. «Ладожские шхеры» практически исчезают со страниц местных газет. Сложившейся ситуацией воспользовались лесозаготовители, получившие в аренду 67\% площади земель лесного фонда территории предполагавшегося парка: крупнейшим арендатором стало ЗАО «Комилесзаготпром», контролировавшее 90\% всех арендованных земель [Эколого-экономическое обоснование 2011, с. 83, 85]. Кроме того, было выдано шесть лицензий на разведку и добычу полезных ископаемых на территории «Ладожских шхер». Также в этот период возобновилось дачное строительство: к 2011 г. на территории национального парка и вблизи его границ находились 2279 участков в садоводческих товариществах и 1554 участка, отведенных под подсобное хозяйство или индивидуальное дачное строительство [Эколого-экономическое обоснование 2011, с. 93-94, 97].

\section{Местные жители против создания парка}

Идея создания национального парка была реанимирована в 2007 г. в ходе переговоров между Министерством природных ресурсов РФ и Правительством Карелии. В мае 2009 г. распоряжением Правительства РФ национальный парк «Ладожские шхеры» был вновь внесен в Перечень государственных природных заповедников и национальных парков, которые планировали обустроить до 2010 г.

9 НАРК. Ф. 3750. Оп. 1. Д. 1/20. Л. 45. Справочная информация Госкомитета по туризму Республики Карелия. Без даты. 
Следует сказать несколько слов о самой Сортавале, часть которой оказалась на территории планируемого национального парка. За свою историю этот небольшой город испытал на себе влияние различных культур, и после Второй мировой войны был передан СССР. Финские жители покинули Сортавалу вместе с отступавшими войсками, и она была заселена заново, преимущественно русскими, белорусами и украинцами. Долгое время в городе действовали пограничный режим и въезд по пропускам. Замкнутость города выстраивала систему запретов, в том числе и на формирование городского и пригородного пространства, тем более что для первого поколения жителей сам город был чужим. 1990-е годы дали новый импульс для развития Сортавалы, а официальная отмена пограничного статуса позволила жителям города активно осваивать ранее недоступные зоны. Ниже мы продемонстрируем, как повседневные практики горожан стали основой для конфликта между ними и центральной властью и экологами.

За последние 10 лет дискуссия о судьбе ладожских шхер переместилась со страниц местной прессы в интернет. Одной из площадок для обсуждения данной проблемы стал специальный раздел в группе города Сортавала в социальной сети «Вконтакте»,' которая в настоящее время насчитывает около 14 тыс. подписчиков (в городе проживает менее 19 тыс. чел.). В течение семи лет (начиная с апреля 2012 г.) в теме группы «Создание парка “Ладожские шхеры”. Голосуем!» было опубликовано более 10 тыс. сообщений, большинство из которых выражали отрицательное отношение к устройству парка ${ }^{10}$. Мотивация участников дискуссии при этом обрела разновекторную направленность. Важнейшим аргументом «против» стал фактор потребления и использования территории в индивидуальных целях: "Я смотрю, летом народ с удовольствием там отдыхает, по грибы, по ягоды, на рыбалочку!!! Как только сделают парк, сразу забудьте про это» ${ }^{11}$ (Татьяна С., 22 мая 2011); «я, например, зимой там рыбачу и не вижу смысла заповедной зоны» (Вячеслав М., 24 апреля 2012); «не повезет тем, у кого дачи попадут в территории парка - им даже нельзя будет картошку садить» (Владимир Г., 28 апреля 2012); «почему мы должны уйти от воды сегодня?» (Сергей Х., 16 мая 2012); «8 лет не был в Сортавале. Друзья говорили, что скоро не попасть будет на рыбалку и за ягодами, и они готовятся стать партизанами» (Игорь С., 8 июня 2014).

Идея национального парка, заключавшаяся в переводе этого пространства в объект визуального потребления, полностью противоречит интересам местных жителей, поскольку природный ландшафт для местных - это объект материального потребления присвоенного пространства. Федеральный закон «Об особо охраняемых природных территориях» запрещает прибрежное рыболовство и заготовку пригодных для употребления в пищу лесных ресурсов национальных парков. Кроме того, закон предусматривает взимание платы за посещение физическими лицами территорий национальных парков, «порядок определения которой устанавливается федеральным органом исполнительной власти» [Федеральный закон 1995] ${ }^{12}$.

\footnotetext{
10 В указанной группе существовали и другие обсуждения парка, которые, впрочем, не стали массовыми.

11 Здесь и далее орфография и пунктуация сохранены.

12 Использование природных ресурсов национальных парков не всегда находится под строгим запретом. Так, например, в парке «Паанаярви» разрешен лов ценной рыбы кумжи, но только по лицензии и только в ограниченное время.
} 
Противники создания парка также отмечали неизбежное ограничение свободы перемещения: «Создав национальный парк и загнав жителей в определенные строгие рамки прожсивания, государство тем самым организует "человеческий зоопарк”. Вот Вы хотели бы жить в зоопарке? Сюда на ходи, то не делай. Не похоже ли это на тюремную зону?» (Геннадий В., май 2011); «границы таковы, что на катере не проехать к островам зоны познавательного туризма» (Вероника Л., 24 апреля 2012); «почему мне вдруг нельзя посещать ни с того ни с сего то, что попадет в заповедную зону?» (Владимир Г., 28 апреля 2012); «все хорошо, но куда расти городу? Не отберем ли мы сами у себя возможность селиться и жить не в лесу, а в красивом и живописном месте?» (Сергей Х., 5 мая 2012); «людей хотят убедить в том, что ограничение в свободе передвижения будет им на благо» (Максим С., 10 декабря 2012). В приведенных высказываниях речь идет не о собственности, дачах или домах, а именно о маршрутах, освоении и присвоении топографического пространства. Оставаясь практически невидимыми для стороннего наблюдателя, маршруты или практики сформировали новое городское пространство, на которое претендовал национальный парк.

В дискуссии фигурировали термины «резервация» (в данном случае речь идет о собственных границах города) и «нацзона» как синоним национального парка: «Это и ждет сортавальщев - резерващия» (Сергей Ч., 15 декабря 2014); «дружными рядами в резервачию, господа» (Ольга Ц., 31 января 2018); «НАЦЗОНА - это вид рейдерского захвата» (Владимир Ш., 17 октября 2014). Здесь стоит добавить, что сам термин «национальный парк» был достаточно новым не только для Республики Карелия, но и для страны в целом. Система охраны природы в виде заказников и заповедников, существовавшая в СССР, строилась на принципе сохранения природы не для человека, а от человека. Поэтому национальный парк, также предполагавший хоть небольшую, но все же закрытую заповедную зону, воспринимался как запрет, а не как возможность. Термин «зона» был подхвачен районной газетой «Ладога-Сортавала», опубликовавшей статью одного из читателей под броским названием «Шаг вправо, шаг влево - расстрел?» [Вансовская 2012]. Громкая публикация представляла парк в самом невыгодном свете: «Зона - это слово у многих вызывает однозначную ассоциацию - охраняемую территорию, где живут люди, преступившие закон. $<\ldots .>$ Какое же преступление в своей жизни совершили тысячи сортавальцев, чтобы пожизненно оказаться “на зоне”?» [Вансовская 2012]. Впрочем, позиция газеты по отношению к национальному парку в целом была благожелательной [Кокко, Соколов 2013].

Факторы потребления и присвоения пространства неизбежно включили в дискуссию противопоставление «своего» и «чужого», где в роли последнего традиционно выступили москвичи: «Не потому ли все это происходит, что, если не будет предприятий, на которых можно работать, люди сами уедут отсюда? И освободят территорию для питериев-москвичей с большими кошельками. Почему Москва так сильно заботится о нашей территории?» (Светлана Ч., 16 мая 2012); «я против этого: весь город будет усеян москвичами, которые не будут знать, где остановиться (в намем городе 4 гостиницы)» (Лука Ю., 3 июня 2012); «а еще больше удивляет принуждение к уединению властей. Им не живется у себя в мирке, в Москве. Мы заслужили жить здесь, а не выживать из-за того, что кто-то там хочет природы. Отдыхайте за деньги, а не отбирайте тот же отдых у обычных людей» (Татьяна С., 15 июля 2012); «цель создания 
парка - захват оного москвичами» (Владимир Ш., 27 февраля 2013); «территория Приладожья - наш дом, наша земля, и мне, и еще 10000 жителей не нужны ни зоны, ни московские хозяева. Нам не нужен нацппрк!» (Сергей Ч., 10 декабря 2014).

Также в качестве «чужого» выступал расплывчатый образ вип-персоны, обладающей широкими возможностями: «Bbl прекрасно все знаете, где и какие поселения уважаемых персон, входящие в планируемую территорию парка, уже есть» (Сергей Х., 8 мая 2012); «под предлогом охраны природы хотят создать закрытую ВИПзаимку, чтобы к той же Марьялахти аборигень и нос не совали» (Владимир Ш., 17 октября 2014); «я против создания парка. Начнется красиво, а потом по берегу вырастут элитные коттеджи» (Владимир Ш., 11 января 2016).

Некоторые горожане заняли выжидательную позицию: они не выступали против парка, а были обеспокоены лишь судьбой своей собственности: «Да мне уже все равно: сегодня нам сказали, что наш район не попадает в нацпарк» (Ирина К., 16 мая 2012); «зачем панику поднимать? Ойявойс и Ламберг не тронут - там дома строят, так же, как и при въезде в Чапаевку. Думаю, в парк уйдут дальняя Чапаевка, Пятидворка, Змейный, Лысая. Хотя я за создание парка и на этих землях. У меня там дом, земля, прописка. От нас отступятся» (Тамара Д., 24 мая 2011). Тем самым эта группа горожан конструировала границу между своим пространством и национальным парком, предлагая свое видение решения конфликта между индивидуальным и коллективным.

Стоит отметить, что судьба национального парка обсуждалась также и на других площадках, в частности, на форуме карельской природоохранной региональной общественной организации «СПОК». Аргументы противников парка оказались идентичными, как и некоторые лица, участвующие в обсуждении. Однако, в отличие от группы в «Вконтакте», дискуссия на сайте «СПОК» широкую аудиторию не привлекла.

Доводы немногочисленных сторонников парка, участвовавших в дискуссиях на перечисленных выше площадках, оказались неубедительными. Аргументы в пользу сохранения природы для общего пользования и гарантии соблюдения прав собственников тонули в общем негативном отношении к парку. Причину этого разработчики проекта национального парка и его защитники видели в недостаточной информированности местных жителей, в деятельности инициативной группы во главе с бывшим главой местного самоуправления города Сортавала В. Варья, которая «распускает страшилки» и «страшные сказки» [Морозова, Гурова, Козырева, Кулакова, Хаапала 2001, с. 25; Общественные слушания 2011; Национальный парк «Ладожские шхеры» 2014]. Это утверждение было верно лишь отчасти: в действительности речь шла о присвоении жителями города новой топографической системы, на которую претендовал национальный парк.

Голосование в социальной сети, в котором приняли участие около 700 чел., подтвердило негативное отношение к созданию парка: «за» высказались 20\%, $5 \%$ ответили «мне все равно», а остальные участники идею не поддержали ${ }^{13}$. 8 июня 2011 г. в Сортавале были проведены общественные слушания, которые переросли в стихийный митинг. Актовый зал музыкальной школы не смог вместить всех желающих, и собрание было перенесено на городской стадион, где собрались

13 https://vk.com/topic-40121_26377619 
примерно 600 чел. Подавляющее число участников митинга высказались против организации национального парка, а голоса экологов опять не были услышаны [Общественные слушания 2011].

Более того, борьба против устройства национального парка стала объединяющим фактором горожан и власти, итогом чего явилось решение Совета Сортавальского муниципального района от 30 ноября 2011 г., отменявшее собственное Постановление 1990 г. «О природном парке “Ладожские шхеры”». Вместо этого Совет постановил «не давать согласия Правительству Республики Карелия на включение территории Сортавальского муниципального района в состав проектируемого национального парка “Ладожские шхеры”» [Об отмене Решения 2011; Об отказе в согласии включения территории 2011]. Спустя год после общественных слушаний на стадионе горожане провели новый митинг, на котором была принята резолюция против «Ладожских шхер», которая была подписана 9,5 тыс. жителей Сортавалы [Митинг в Сортавала 2011].

Аргументы местной администрации, депутатов городского совета и Законодательного собрания Республики Карелия (далее - ЗС РК) оказались во многом схожими с мнением местных жителей. Интервью, собранные по горячим следам в апреле и мае 2013 г., демонстрируют, как представители власти отстаивают права города на формирование пригородного пространства, проводят границу у своей территории и апеллируют к термину «резерват», ограничивающему права горожан: «Честно сказать, большое упущение, что сняли погранзону. Не было чужих. Город жил в своей атмосфере. <...> Знаете, что здесь всех делает сплоченными? Это дачные участки, рыбалка. Понимаете? Город <...> раньше, когда в городе было два пирса и 2 тыс. катеров, понимаете? Люди жили Ладогой. Они могли похвастаться, какая у него машина, какой у него мотор, какая у него лодка» ${ }^{14}$, «я выступил в 2011 г. против национального парка. На сегодняиний момент, наше законодательство несовершенно, оно однобоко в пользу московских господ, которые готовы купить здесь что угодно. Если сделать парк, то они будут делать все, а у людей не будет ничего» ${ }^{15}$; «мы хотим сохранить наш район, мьл хотим нормальное будущее, не в рамках резервата, а нормально развиваясь и пользуясь преимуществом нашего географического положения. Люди хотят жить на этой территории, хотят ее развивать, это здорово» ${ }^{16}$.

Таким образом, общая для представителей власти и горожан логическая цепочка, обосновывающая их права на эту территорию, выглядит следующим образом:

- обозначение территории («раньше была погранзона»);

- присвоение пространства («это наша земля»);

- потребление природы (дачи, рыбалка, отдых);

- защита земли (парк для москвичей, а не для местных);

- использование ярлыков («зона», «резервация»).

Дискуссия вокруг создания национального парка стала не только фактором, объединяющим власть и горожан, но и превратилась в предвыборный лозунг пар-

\footnotetext{
14 Интервью с депутатом Сортавальского городского совета, интервьюер Яровой Г., апрель 2013 г.

15 Интервью с представителем администрации Сортавальского городского поселения, интервьюер Яровой Г., апрель 2013 г.

16 Интервью с депутатом ЗС РК, интервьюер Яровой Г., апрель 2013 г.
} 
тии «Справедливая Россия» на выборах 2011 г. в ЗС РК. «Основополагающей идеей на протяжении двух лет, с чем мы еще на выборы шли, наше основное выборное обещание - не допустить размещения национального парка там, бороться с этой $u д е е \breve{u}\rangle^{17}$. Впрочем, на республиканском уровне эта идея не получила поддержку ни главы региона, ни депутатов ЗС РК. Последние отказались принимать обращение к премьер-министру РФ против национального парка, что стало крупным поражением противников парка и фактически завершило дискуссию вокруг «Ладожских шхер» [Депутатский комитет не поддержал 2012].

Официально точка в этом вопросе была поставлена 28 декабря 2017 г. постановлением правительства РФ [О создании национального парка 2018]. При этом вопрос определения границ парка и выведения частных хозяйств с его территории остается ключевым, и эта работа ведется на протяжении 2018-2019 гг. ${ }^{18}$. Таким образом, интересы местных жителей при создании парка оказались формально учтены, однако конфликт остался неразрешенным. Национальный парк в восприятии горожан пересекает невидимую границу, разрушает выстроенные ими маршруты, заставляя город сжиматься до конкретного места и лишая его освоенного пространства. Основная идея национального парка - превращение ландшафта в объект визуального потребления - остается невостребованной местными жителями. В их восприятии парк отождествляется с москвичами, питерцами, богачами, выживающими местное население в резервацию. Рекреация парка, ограниченная Федеральным законом «Об особо охраняемых природных территориях», не только не предполагает привычное местным жителям потребление природы (сбор ягод и грибов, рыбалку), но и, вероятно, допускает введение платного входа на территорию парка.

Корни конфликта вокруг территории Северного Приладожья стоит искать не только в конце 1980-х гг. и первых попытках реализации идеи создания национального парка. Новые жители Сортавалы, заселившие город после Второй мировой войны, не воспринимали уникальные природные территории в качестве национальных ландшафтов. В отличие от прежнего финского населения, жители Сортавалы (да и граждане СССР в целом) не связывали свою национальную идентичность с посещением ладожских шхер. Таким образом, ландшафт вокруг города в советское и постсоветское время являлся не более чем красивой природой с усиливающимся утилитарным оттенком.

Неприятие местными жителями «Ладожских шхер» объясняется отчасти и новизной самого концепта национального парка для страны. Советская система охраны природы, направленная на сохранение и консервацию природных ландшафтов в рамках заповедников и заказников, не предусматривала рекреационного использования этих территорий. Поэтому создание национального парка в $\mathrm{Ce}-$ верном Приладожье воспринимается как ограничение, а не возможность. Вполне очевидно, что упорядочивание природопользования, которое привносит парк, нарушает установленные местными жителями порядки и обычаи, но как только граница парка сдвигается и перестает вторгаться в жизненное пространство горожан, конфликт сразу теряет свою остроту.

\footnotetext{
17 Интервью с депутатом ЗС РК, интервьюер Яровой Г., апрель 2013 г.

18 Стоит пояснить, что на момент написания статьи (апрель 2019 г.) проект Положения о национальном парке «Ладожские шхеры» находится в стадии разработки, а дирекция парка на этот момент не создана.
} 


\section{Литература}

Аксенова О.В. (ред.) (2017) Асимметрия жизни современного российского общества: соотношение традиций и инноваций. М.: ФНИСЦ РАН.

Вансовская Е. (2012) Шаг вправо, шаг влево - расстрел? // Ладога-Сортавала. 25 июня 2012. С. 2.

Ведлозерская Н. (2001) Туриста здесь и дети ждут // Северный курьер. 13 марта 2001. С. 2. Водлозерье - не только парк, но и люди, брошенные властями - вчера и забытые - сегодня (1995) // Северный курьер. 1 февраля 1995. С. 3.

Глибина Е. (2012) Думали - национальное бедствие, оказалось - благо! // Ладога-Сортавала. 21 сентября 2012.

Громцев Н. (2001) Как привлечь к нам туристов? // Северный курьер. 21 июня 2001. С. 2.

Депутатский комитет не поддержал обращение к премьер-министру РФ против национального парка «Ладожские шхеры» (2012) // Spok-karelia.ru. 16 марта 2012 // http://spok-karelia.ru/2012/03/news/2771/\#more-2771

Ефременко Д. В. (2006) Эколого-политические дискурсы. Возникновение и эволюция. М.: ИНИОН РАН.

Жуков А. (1995) Парк в Ладожских шхерах // Северный курьер. 1 февраля 1995. С. 2.

Интервью с ведущим специалистом Госкомитета РК по физической культуре, спорту и туризму Крутовской М. (1999) // Северный курьер. 17 февраля 1999. С. 4.

Интервью с первым замминистра экологии и природных ресурсов Ширлиным А. (1997) // Северный курьер. 4 февраля 1997. С. 3.

Интервью с председателем Госкомитета РК по физической культуре, спорту и туризму Шороховым Е. (1998) // Северный курьер. 4 ноября 1998. С. 4.

Интервью с руководителем проекта Хогмандером Й. (1999) // Северный курьер. 25 сентября 1999. С. 2.

Казберович Н. (2000) Станет ли экологическая «Мекка» туристской? // Северный курьер. 12 августа 2000. С. 1.

Карху Я., Осипов А.Ю. (2017) Туризм в северном измерении (некоторые итоги IX Международного конгресса арктических социальных наук) // Арктика и Север. № 28. С. 118-124.

Кокко Л., Соколов В. (2013) «Ладожские шхеры»: дискуссия в Питкяранте // Ладога-Сортавала. 5 апреля 2013.

Кравченко А.В. (2001) Национальный парк «Ладожские шхеры»: предложения к организации. Петрозаводск.

Мальковский В., Тимофеев В. (1998) Страсти по парку «Ладожские шхеры»: осторожно, гигантомания! // Северный курьер. 14 февраля 1998. С. 5.

Митинг в Сортавала 22.06.2012: послесловие (2012) // Ладожская хроника. 8 июля 2012 // http://www.ladoga-park.ru/a120710151854.html

Морозова Т., Гурова С., Козырева Г., Кулакова Л., Хаапала Х. (2001) Социально-экономические предпосылки развития особо охраняемых природных территорий в приграничной полосе Республики Карелия. Петрозаводск-Хельсинки.

Назаров В. (1992) В угоду заказчику // Северный курьер. 10 октября 1992. С. 3.

Национальный парк «Ладожские шхеры»: правда против мифа (2014) // Красное знамя. Октябрь 2014. № 2. С. 1.

Некрасов М. (1999) Национальные парки: плюсы и минусы // Северный курьер. 10 марта 1999. С. 5.

О создании национального парка «Ладожские шхеры» (Республика Карелия) (2018) // Government.ru. 14 января 2018 // http://government.ru/docs/30864/

Об отказе в согласии включения территории Сортавальского муниципального района в границы национального парка «Ладожские шхеры» (2011) // Рк-сортавала.рф. 30 ноября $2011 / / \mathrm{http}: /$ www.ladoga-park.ru/a120521024055.html

Об отмене Решения II сессии XXI созыва Сортавальского городского Совета народных депутатов от 28 июня 1990 г. «О природном парке «Ладожские шхеры» (2011) // Рк-сортавала.рф. 30 ноября 2011 // http://www.ladoga-park.ru/a120521023342.html 
Общественные слушания в Сортавале по созданию национального парка «Ладожские шхеры» превратились в несанкционированный митинг (2011) // Spok-karelia.ru. 9 июня 2011 // http://spok-karelia.ru/2011/06/news/2191/comment-page-1/\#comments

Прокопенко Т. (1999) Туризм - это выгодно // Северный курьер. 23 сентября 1999. С. 1.

Садовой А.Н. (ред.) (2012) Этнические, экологические и экономические аспекты развития туризма на особо охраняемых природных территориях горных экосистем мира. Чебоксары: Пегас.

Сазонов С., Кравченко А., Кузнецов О. (1997) Судьба Ладожских шхер // Северный курьер. 21 августа 1997. С. 3.

Семенов Я. (1994) Парк «Паанаярви»: год спустя // Приполярье. 20 апреля 1994. С. 1-2.

Серто М. де (2013) Изобретение повседневности. 1. Искусство делать. СПб.: Европейский университет в Санкт-Петербурге.

Смирнова И. (2001) Туристскими тропами // Северный курьер. 24 марта 2001. С. 1.

Степаницкий В.Б., Крейндлин В.Л. (2004) Государственные природные заповедники и национальные парки России: угрозы, неудачи, упущенные возможности. М.: Гринпис России.

Сыстра Ю. (1997) Судьба Ладожских шхер // Северный курьер. 26 апреля 1997. С. 5.

Тимофеев В. (1) (1991) Ждет ли Ладогу судьба Арала // Ленинская правда. 30 мая 1991. C. 2 .

Тимофеев В. (2) (1991) Опала // Ленинская правда. 9 сентября 1991. С. 3-4.

Тимофеев В. (1998) Эмиссары ЮНЕСКО в парке «Водлозерский» // Северный курьер. 10 июля 1998. С. 2.

Федеральный закон (1995) от 14 марта 1995 г. № 33-Ф3 «Об особо охраняемых природных территориях» в редакции закона 486 от 28.12.2016 // Garant.ru // http://base.garant. $\mathrm{ru} / 10107990 /$

Экологический митинг (1991) // Северный курьер. 13 декабря 1991. С. 1.

Эколого-экономическое обоснование для образования национального парка «Ладожские шхеры» (2011). М.

Яницкий О.Н. (2016) Экосоциальные исследования: междисциплинарная методология, теория, практика. М.: Институт социологии РАН.

Hall C.M., Boyd S. (eds.) (2005) Nature-based Tourism in Peripheral Areas: Development or Disaster? Clevedon: Channel View Publications.

Fullagar S., Markwell K., Wilson E. (eds.) (2012) Slow Travel and Tourism: Experiences and Mobilities, Buffalo: Channel View Publications.

Laatokan pohjoisrannikon kulttuuriympäristö: suomalainen kulttuuriperintö Laatokan pohjoisrannikon maisemassa (1998), Helsinki: Suomen Ympäristökeskus.

Rajaseutujen matkailuopas (1927), Helsinki: Suomen Rajaseutuyhdistys.

Siiskonen H. (1994) Matkaoppaiden Karjala maailmansotien välillä // Kahden Karjalan välillä, kahden Riikin riitamaalla. Studia Carelica humanistica (ed. T. Hämynen), Joensuu, pp. 123-134.

Page S.J., Dowling R.K. (2002) Ecotourism, Harlow: Prentice Hall.

Vartiainen E. (1932) Matkailuopas, Sortavala: OY Raamattutalon Kirjapaino. 


\title{
The Commodification of Nature: a Case Study of the "Ladoga Skerries" National Park
}

\author{
A. OSIPOV*, M. LÄHTEENMÄKI**, O. ILMOLAHTI***, J. KARHU****
}

\begin{abstract}
*Aleksandr Osipov - PhD in History, Researcher, Department of Geographical and Historical Studies, University of Eastern Finland. Address: Box 111, 80100 Joensuu, Finland. E-mail: alexander.osipov@uef.fi

**Maria Lähteenmäki - PhD in Philosophy, Professor of History, Department of Geographical and Historical Studies, University of Eastern Finland. Address: Box 111, 80100 Joensuu, Finland. E-mail: maria.lahteenmaki@uef.fi

***Oona Ilmolahti - PhD in Philosophy, Researcher, Department of Geographical and Historical Studies, University of Eastern Finland. Address: Box 111, 80100 Joensuu, Finland. E-mail: oona.ilmolahti@uef.fi

****Jani Karhu - MA, Researcher, Department of Geographical and Historical Studies, University of Eastern Finland. Address: Box 111, 80100 Joensuu, Finland. E-mail: jani. karhu@uef.fi
\end{abstract}

Citation: Osipov A., Lähteenmäki M., lmolahti O., Karhu J. (2019) The Commodification of Nature: a Case Study of the "Ladoga Skerries" National Park. Mir Rossii, vol. 28, no 3, pp. 113-131 (in Russian). DOI: 10.17323/1811-038X-2019-28-3-113-131

\begin{abstract}
This article examines the issue of the commodification of North Ladoga and different views on the use of natural resources. The fate of this unique natural landscape exposed to serious human impact has become the focus of long-term discussions between the authorities at different levels, scholars and local citizens. The foundation of the "Ladoga Skerries" national park was warranted by the need to preserve a unique natural complex, but affected the rights of the local population, who united against this idea. This study is based on unpublished archival sources, interviews and data from various internet forums. Applying a multidisciplinary approach, the authors demonstrate how the natural landscapes of North Ladoga have become visual objects and how ecotourism has become a tool for the park's commodification. The local population considers this area their living space and an object of material consumption. Thus, the case study in this article reveals the classic contradiction between the collective and the individual. From the analysis of the local population's views we conclude that the conflict is not simply centered on the various types of the commodification of nature. The national park violates the invisible borders surrounding what the local people perceive as their living space. The mechanism of such a perception could be presented as a chain: the marking of territory, the appropriation of space, the consumption of nature and defending the land. The authors reveal how this conflict has become a higher-level political issue, in which the opponents of the national park have become defeated, leaving the conflict unresolved.
\end{abstract}

Key words: commodification, living space, national park, natural landscape, tourism, social-environmental conflict 


\section{References}

Aksenova O.V. (ed.) (2017) Asimmetriya zhizni sovremennogo rossijskogo obshchestva: sootnoshenie traditsij i innovatsij [The Asymmetry of Life of Modern Society: Relationship between Traditions and Innovations], Moscow: FNISC RAN.

Glibina E. (2012) Dumali - natsional'noe bedstvie, okazalos' - blago [National Disaster Turned Good]. Ladoga-Sortavala, September 21, 2012.

Gromtsev N. (2001) Kak privlech k nam turistov [How We Should Attract Tourists]. Severnyj kur'er, June 21, 2001, p. 2.

Deputatskij komitet ne podderzhal obrashchenie k prem'er-ministru RF protiv natsional'nogo parka «Ladozhskie shkhery» (2012) [The Deputy Committee Turns Down on RF's Prime Minister's Request Against the "Ladoga Skerries" National Park]. Spok-karelia.ru, March 16, 2012. Available at: http://spok-karelia.ru/2012/03/news/2771/\#more-2771, accessed 15.05.2019.

Efremenko D.V. (2006) Ekologo-politicheskie diskursy. Vozniknovenie i evolyutsiya [Ecological and Political Discourses. The Emergence and Development], Moscow: INION RAN.

Ekologicheskij miting (1991) [Ecological Rally]. Severnyj kur'er, December 13, 1991, p. 1.

Ekologo-ekonomicheskoe obosnovanie dlya obrazovaniya natsional'nogo parka "Ladozhskie shkhery» (2011) [The Ecological and Economic Justification of the Establishment of the "Ladoga Skerries" National Park], Moscow.

Federalnyj zakon ob osobo okhranyaemykh prirodnykh territoriyakh ot $14.03 .1995 \mathrm{v}$ redaktsii Zakona 486 ot 28.12.2016 [The Federal Law "On the Specially Protected Nature Areas"]. Garant.ru. Available at: http://base.garant.ru/10107990/, accessed 15.05.2019.

Fullagar S., Markwell K., Wilson E. (eds.) (2012) Slow Travel and Tourism: Experiences and Mobilities, Buffalo: Channel View Publications.

Hall C.M., Boyd S. (eds.) (2005) Nature-based Tourism in Peripheral Areas: Development or Disaster? Clevedon: Channel View Publications.

Interv'yu s pervym zamministra ekologii i prirodnykh resursov Shyrlinym A. (1997) [An Interview with Shyrlin A., the First Deputy Minister of Ecology and Natural Resources]. Severnyj kur'er, February 4, 1997, p. 3.

Interv'yu s predsedatelem Goskomiteta RK po fizicheskoj kul'ture, sportu i turizmu Shorokhovym E. (1998) [An Interview with Shorokhov E., the Chairman of the State Committee of Physical Culture, Sport and Tourism of the Republic of Karelia]. Severnyj kur'er, November 4, 1998, p. 4.

Interv'yu s rukovoditelem proekta Hogmanderom J. (1999) [An Interview with Högmander J., the Head of the Project]. Severnyj kur'er, September 25, 1999, p. 2.

Interv'yu s vedushchim spetsialistom Goskomiteta RK po fizicheskoj kul'ture, sportu i turizmu Krutovskoj M. (1999) [An Interview with Krutovskaja M., the Leading Expert of the State Committee of Physical Culture, Sport and Tourism of the Republic of Karelia]. Severnyj kur'er, February 17, 1999, p. 4.

Kazberovich N. (2000) Stanet li ekologicheskaya «Mekka» turistskoj? [Will the Ecological "Mekka" be Tourist?]. Severnyj kur'er, August 12, 2000, p. 1.

Karhu J., Osipov A.Y. (2017) Turizm v severnom izmerenii (nekotorye itogi IX Mezhdunarodnogo kongressa arkticheskikh sotsial'nykh nauk) [Tourism in the Northern Dimension (Some Results of the Ninth International Congress of Arctic Social Sciences)]. Arktika i Sever, no 28, pp. 118-124.

Kokko L., Sokolov V. (2013) «Ladozhskie shkhery»: diskussiya v Pitkyarante (2013) [“Ladoga Skerries": Discussion in Pitkyaranta]. Ladoga-Sortavala, April 5, 2013.

Kravchenko A.V. (2001) Natsional'nyj park «Ladozhskie shkhery»: predlozheniya k organizatsii [The "Ladoga Skerries" National Park: Proposals for the Foundation], Petrozavodsk.

Laatokan pohjoisrannikon kulttuuriympäristö: suomalainen kulttuuriperintö Laatokan pohjoisrannikon maisemassa (1998), Helsinki: Suomen ympäristökeskus.

Mal'kovskij V., Timofeev F. (1998) Strasti po parku «Ladozhskie shkhery»: ostorozhno, gigantomaniya! [Passions for the "Ladoga Skerries" Park: Warning, Gigantomania!]. Severnyj kur'er, February 14, 1998, p. 5. 
Miting v Sortavala 22.06.2012: posleslovie (2012) [Meeting in Sortavala 22 June 2012: Afterword]. Ladozhskaya khronika, July 8, 2012. Available at: http://www.ladoga-park.ru/a120710151854.html, accessed 15.05.2019.

Morozova T., Gurova S., Kozyreva G., Kulakova L., Haapala H. (2001) Sotsial'no-ekonomicheskie predposylki razvitiya osobo okhranyaemykh prirodnykh territorij v prigranichnoj polose Respubliki Kareliya [The Social-economic Preconditions of Development of Specially Protected Nature Areas on the Border Strip of the Republic of Karelia], Petrozavodsk, Helsinki.

Natsional'nyj park «Ladozhskie shkhery»: pravda protiv mifa (2014) [The "Ladoga Skerries" National Park: Truth against Myth]. Krasnoe znamya, October 2014, no 2, p. 1.

Nazarov V. (1992) V ugodu zakazchiku [In Customer's Favor]. Severnyj kur'er, October 10, 1992, p. 3.

Nekrasov M. (1999) Natsional'nye parki: plyusy i minusy [National Parks: Pros and Cons]. Severnyj kur'er, March 10, 1999, p. 5.

O sozdanii nacional'nogo parka «Ladozhskie shkhery» (Respublika Kareliya) [On the Foundation of the "Ladoga Skerries" National Park] (2018). Government.ru, January 14, 2018. Available at: http://government.ru/docs/30864/, accessed 15.05.2019.

$\mathrm{Ob}$ otkaze $\mathrm{v}$ soglasii vklyucheniya territorii Sortaval'skogo munitsipal'nogo rajona $\mathrm{V}$ granitsy natsional'nogo parka «Ladozhskie shkhery» [On the Refusal of Including the Sortavala Municipal Area in the Boundaries of "Ladoga Skerries" National Park] (2011). Ladozhskaya khronika, November 30, 2011. Available at: http://www.ladoga-park.ru/a120521024055.html, accessed 15.05.2019.

Ob otmene resheniya II sessii XXI sozyva Sortaval'skogo gorodskogo Soveta narodnykh deputatov ot 28 iyunya $1990 \mathrm{~g}$. «O prirodnom parke «Ladozhskie shkhery» [On the Cancellation of the Decision of the II Session of the XXI Congress of the Sortavala City Council Dated 28 June 1990 "Nature Park "Ladoga Skerries"] (1990). Ladozhskaya khronika, November 30, 2011. Available at: http://www.ladoga-park.ru/a120521023342.html, accessed 15.05.2019.

Obshchestvennye slushaniya v Sortavale po sozdaniyu natsional'nogo parka «Ladozhskie shkhery» prevratilis' v nesanktsionirovannyj miting [Public Hearing Concerning the Establishment of the "Ladoga Skerries" National Park Turned into Unauthorized Rally] (2011). Spok-karelia.ru, June 9, 2011. Available at: http://spok-karelia.ru/2011/06/news/2191/comment-page-1/\#comments, accessed 15.05.2019.

Page S.J., Dowling R.K. (2002) Ecotourism, Harlow: Prentice Hall.

Prokopenko T. (1999) Turizm - eto vygodno [Tourism is Profitable]. Severnyj kur'er, September 23, 1999, p. 1.

Rajaseutujen matkailuopas (1927), Helsinki: Suomen Rajaseutuyhdistys.

Sadovoj A.N. (ed.) (2012) Etnicheskie, ekologicheskie i ekonomicheskie aspekty razvitiya turizma na osobo okhranyaemykh prirodnykh territoriyakh gornykh ekosistem mira [The Ethnic, Ecological and Economic Aspects of the Development of Tourism in Specially Protected Nature Areas of the Mountain Ecosystems of the World], Cheboksary: Pegas.

Sazonov S., Kravchenko A., Kuznecov O. (1997) Sud'ba ladozhskikh shkher [The Fate of Ladoga Skerries]. Severnyj kur'er, August 21, 1997, p. 3.

Semenov Ya. (1994) Park «Paanajarvi»: god spustya [The Paanajarvi Park: One Year Later]. Pripolyar'e, April 20, 1994, pp. 1-2.

Serto M. de (2013) Izobretenie povsednevnosti [The Practice of Everyday Life], Saint Petersburg: Evropeiskij Universitet v Sankt-Peterburge.

Siiskonen H. (1994) Matkaoppaiden Karjala maailmansotien välillä. Kahden Karjalan välillä, kahden Riikin riitamaalla. Studia Carelica humanistica (ed. Hämynen T.), Joensuu, pp. 123-134.

Smirnova I. (2001) Turistskimi tropami [On the Tourist Paths]. Severnyj kur'er, March 24, 2001, p. 1. Stepanitskij V.B., Krejndlin V.L. (2004) Gosudarstvennye prirodnye zapovedniki i natsional'nye parki Rossii: ugrozy, neudachi, upushchennye vozmozhnosti [State Nature Reserves and National Parks of Russia: Threats, Failures, Missed Opportunities], Moscow: Grinpis Rossii.

Systra Y. (1997) Sud'ba Ladozhskikh shkher [The Fate of Ladoga Skerries]. Severnyj kur'er, April 26, 1997, p. 5. 
Timofeev V. (1) (1991) Zhdet li Ladogu sud'ba Arala [Will the Fate of Ladoga be the Same as the One of the Aral Sea?]. Leninskaya Pravda, May 30, 1991, p. 2.

Timofeev V. (2) (1991) Opala [Proscription]. Leninskaya Pravda, September 9, 1991, pp. 3-4.

Timofeev V. (1998) Emissary UNESCO v parke «Vodlozerskij» [Emissaries of UNESCO in the "Vodlozero" National Park]. Severnyj kur'er, July 10, 1998, p. 2.

Vansovskaya E. (2012) Shag vpravo, shag vlevo - rasstrel? [Step Right, Step Left - Shooting?]. Ladoga-Sortavala, June 25, 2012, p. 2.

Vartiainen E. (1932) Matkailuopas, Sortavala: OY Raamattutalon Kirjapaino.

Vedlozerskaya N. (2001) Turista zdes' i deti zhdut [Tourists Are Expected Here Even by Kids]. Severnyj kur'er, March 13, 2001, p. 2.

Vodlozer'e - ne tol'ko park, no i lyudi, broshennye vlastyami - vchera i zabytye - segodnya (1995) [Vedlozero - Not Just a Park, But Also People, Abandoned by the Authorities Yesterday and Forgotten Today]. Severnyj kur'er, February 1, 1995, p. 3.

Yanitskij O.N. (2016) Ekosotsil'nye issledovaniya: mezhdistsiplinarnaya metodologiya, teoriya, praktika [Environmental Sociology: Interdisciplinary Methodology, Theory and Practice], Moscow: IS RAN.

Zhukov A. (1995) Park v Ladozhskikh shkherakh [Park in the Ladoga Skerries]. Severnyj kur'er, February 1, 2001, p. 2. 